\title{
CITRA KEPAHLAWANAN DALAM FILM-FILM BERLATAR SEJARAH PADA LAYAR LEBAR INDONESIA PASCA-RUNTUHNYA REZIM SOEHARTO (STUDI KASUS FILM SOEGIJA, HABIBIE-AINUN, DAN HADROTUSSYAIKH SANG KIAI)
}

\author{
Ghifari Yuristiadhi Masyhari Makhasi \\ Program Studi Kepariwisataan, Sekolah Vokasi, Universitas Gadjah Mada \\ ghifari.yuristiadhi@ugm.ac.id
}

\begin{abstract}
In Indonesia, film as a popular media developed significantly with the presence of films in various genres, one of which is historical film. Post-reform, various historical films emerged that were not previously discovered during the New Order era. As is known, historical films in the New Order era were dominated by Soeharto as an actor, these historical films seemed to voice that there were many other heroes who also had contributions to Indonesia. These films then seem to want to show the self (keakuan) and nationalism possessed by these figures. This research wants to show the contestation of the self (keakuan) and nationalism of three films: Soegija, Habibie-Ainun, and Hadrotusyaikh the Kiai. This research is a qualitative descriptive study with a phenomenological approach.
\end{abstract}

Keywords: heroic image, historical film, post-New Order, Soegija film, Habibie-Ainun film, Hadrotussyaikh Sang Kiai film

\section{Intisari}

Di Indonesia, film sebagai media populer berkembang cukup signifikan dengan hadirnya film dalam berbagai genre, salah satunya film sejarah. Pasca reformasi, muncul berbagai film sejarah yang sebelumnya tidak ditemukan pada masa Orde Baru. Sebagaimana diketahui, film-film kesejarahan di masa Orde Baru lebih didominasi Soeharto sebagai aktor, film-film sejarah ini seakan ingin menyuarakan bahwa ada banyak sosok pahlawan lain yang juga memiliki kontribusi untuk Indonesia. Film-film ini kemudian terkesan ingin menunjukkan keakuan dan nasionalisme yang dimiliki oleh sosok-sosok tersebut. Penelitian ini ingin menunjukkan kontestasi keakuan dan nasionalisme dari tiga film: Soegija, Habibie-Ainun, dan Hadrotusyaikh Sang Kiai. Penelitian ini adalah penelitian deskriptif kualitatif dengan pendekatan fenomenologis.

Kata kunci: citra kepahlawanan, film sejarah, pasca-Orde Baru, Film Soegija, Film Habibie-Ainun, Film Hadrotussyaikh Sang Kiai 


\section{PENDAHULUAN}

Turunnya Soeharto pada 21 Mei 1998 ternyata diikuti dengan banyaknya buku yang terbit dalam berbagai macam versi dan sudut pandang, khususnya mengenai hal-hal yang kontroversial selama 32 tahun kepemimpinan presiden kedua Indonesia itu. Isu-isu seputar Gerakan 30 September, diskriminasi etnis Tionghoa di Indonesia ataupun drama di balik turunnya Soeharto menjadi genre baru penerbitan buku di Indonesia. Buku yang dilarang terbit pada masa rezim Soeharto juga bermunculan. Selain itu, menjamurnya biografi ataupun otobiorgafi yang mengisahkan 'keakuan' seorang tokoh dalam banyak peristiwa selama Soeharto bahkan Soekarno memimpin negeri ini juga menjadi sebuah fenomena menarik pascaruntuhnya Soeharto. Gerry van Klinken mencatat, antara tahun 1995-2000, bukubuku biografi dan otobiorgrafi yang terbit mencapai rata-rata 135 buku pertahun (Van Klinken, 2008, 126). Sebuah jumlah yang tidak sedikit.

Selain buku yang memaparkan fakta ataupun biografi/otobiografi, buku-buku teori sejarah pun bermunculan. Jargon 'pelurusan sejarah', 'perspektif baru penulisan sejarah Indonesia', ataupun semangat untuk melepaskan sejarah dari belenggu otoriterian rezim menjadi episteme baru (meminjam Faucould) dalam tradisi akademik sejarah di Indonesia. Bahkan secara khusus pada 2007, ada pernyataan menarik dari Menteri Pendidikan dan Kebudayaan, Juwono Sudarsono yang disampaikan di depan Masyarakat Sejarawan Indonesia bahwa buku Sejarah Nasional Indonesia sudah tidak berlaku lagi. Buku yang menjadi simbol otoritarian rezim Soeharto dalam penulisan sejarah Indonesia tersebut akan diganti dengan buku yang lebih objektif memaparkan fakta-fakta dalam sejarah Indonesia yang ditulis oleh sejarawan dari berbagai wilayah di Indonesia (Adam, 2007, vii- viii)

Kembali kepada fenomena munculnya banyak buku-buku biografi ataupun otobiografi yang menonjolkan 'keakuan' seseorang yang mempunyai peran dan kontribusi besar dalam sebuah rentang sejarah, fakta lain yang muncul bersamaan dengan hal itu adalah banyaknya pengajuan pahlawan nasional ke Direktorat Urusan Kepahlawanan Nasional Kementrian Sosial RI pasca 1998. Banyak orang yang mengajukan gelar yang didefinisikan sebagai "gelar yang diberikan kepada warga Negara Indonesia atau seseorang yang berjuang melawan penjajahan di wilayah yang sekarang menjadi wilayah Negara Kesatuan Republik Indonesia yang gugur atau meninggal dunia demi membela bangsa dan Negara, atau yang semasa hidupnya melakukan tindakan kepahlawanan atau menghasilkan prestasi dan karya yang luar biasa bagi pembangunan dan kemajuan bangsa dan negara Republik Indonesia" . Artinya, banyak orang yang ingin menyematkan gelar pahlawan kepada seseorang yang mungkin terlupa atau sengaja dilupakan untuk disebut pahlawan ketika Orde Baru berkuasa. Pada mas Orde Baru sendiri, rezim lebih fokus membangun citra kepahlawanan Soeharto, melalui monumen, museum, dan film tentunya (Iriwanto, 2018, 87-108)

Berbicara kepahlawanan nasional dengan definisi di atas, perlu digarisbawahi bahwa definisi tersebut menyatakan dua hal yang spefisik tentang siapa pahlawan nasional menurut pemerintah. Pertama adalah "seseorang yang berjuang melawan penjajahan di wilayah yang sekarang menjadi wilayah Negara Kesatuan Republik Indonesia yang gugur atau meninggal dunia demi membela bangsa dan Negara". Sedangkan kedua adalah "seseorang yang semasa hidupnya melakukan tindakan kepahlawanan atau menghasilkan 
prestasi dan karya yang luar biasa bagi pembangunan dan kemajuan bangsa dan negara Republik Indonesia." (Kemensos.go.id, diakses 24 Juni 2013) Namun, sayangnya, definisi pahlawan kemudian menyempit hanya terbatas yang mengangkat senjata dan terlibat dalam dar-der-dor saja dan menafikan yang kedua. Hal ini diamini oleh sebagian masyarakat Indonesia yang masih terjebak bahwa pahlawan hanya diartikan dengan terminologi politik dan belum yang lain, seperti olahraga, seni, temuan ilmiah mutakhir, dsb.

Nasionalisme yang menyala masih dianggap hanya muncul dari perang dan bukan dari ajang yang lain. Itulah mengapa yang terjadi setiap beberapa bulan menjelang 10 November (yang dijadikan hari Pahlawan), kontestasi untuk merebutkan gelar pahlawan bergejolak. Nasionalisme yang menurut Kamus Besar Bahasa Indonesia (KBBI) bermakna "paham (ajaran) untuk mencintai bangsa dan negara sendiri' inilah yang dikontestasikan dan diperebutkan setiap tahun khususnya setelah 1998 (Pusat Bahasa Depdiknas RI, $2008,997)$. Belum cukup nasionalis kalau belum disebut sebagai pahlawan. Begitulah kira-kira yang ada dalam pikiran orang-orang yang berkontestasi. Sebagai contoh, tahun 2012 lalu, ada 9 nama yang lolos untuk dianugrahi gelar pahlawan nasional baru yang diajukan oleh berbagai daerah.

Untuk menunjukkan seberapa besar kecintaan kepada bangsa dan negara tidak cukup hanya dengan ditulis dalam biografi/otobiografi ataupun diberi gelar pahlawan nasional. Media lain yang akan menjelaskan hal-hal yang belum jelas ataupun menjawab keraguan orang atas nasionalisme yang dimiliki seorang tokoh adalah film. Sejak rezim Soeharto berkuasa, sebenarnya film sudah dijadikan sebagai media propaganda nasionalisme. Ketika episteme yang dipakai oleh rezim Soeharto berkuasa bahwasanya nasionalisme itu ditunjukkan dalam rangka menghindari ajaran Komunisme/Marxisme sebagaimana tertuang dalam TAP MPRS No. XXV/MPRS/1966, maka film Pengkhianatan G30S/PKI menjadi bagian dari propaganda nasionalisme itu. Trilogi film Enam Djam di Jogja, Djanur Kuning dan Serangan Fadjar, produk Orde Baru juga berhasil membangun image bahwa nasionalisme itu ada pada diri orangorang yang terlibat dalam perang kemerdekaan dan itu dilakukan oleh para pendiri Orde Baru, salah satunya Soeharto. Pun dengan kehadiran film-film berlatar sejarah yang menjamur setelah runtuhnya Soeharto, dengan episteme kebebasan era reformasi, maka semua berlomba-lomba untuk 'meluruskan sejarah' yang salah tulis atau sengaja ditulis salah dengan ragam nasionalisme yang dipersepsikan masing-masing.

\section{METODE PENELITIAN}

Artikel yang merupakan penelitian deskriptif kualitatif dengan pendekatan fenomenologis ini akan mengulas dan menganalisis singkat 'keakuan' dan penonjolan nasionalisme pada seorang tokoh dalam beberapa film yang berlatar belakang sejarah yang muncul setelah tumbangnya rezim Orde Baru. Dari sekian banyak film berlatar belakang sejarah yang muncul, penulis akan membatasi pada tiga film terbaru berlatar sejarah yang diputar di bioskop-bioskop di Indonesia, yakni Soegija (2012), Habibie dan Ainun (2012) dan Hadrotussyaikh Sang Kiai (2013).

Satu hal yang menarik dari ketiganya adalah sekelompok orang yang berada di balik pembuatan film-film tersebut. Apa yang diinginkan oleh mereka dengan hadirnya film-film itu? Nasionalisme seperti apa yang ingin ditampilkan dalam film-film tersebut? Sejauh apa pengaruhnya bagi konsumen 
film? Artikel ini akan menganalisis ketiga film tersebut dengan menggunakan metode analisa percakapan dan konten yang mencoba mengumpulkan data percakapan dari beberapa scene film serta beberapa konten pokok film dan dipilih unsur yang terkait dengan nasionalisme kemudian dianalisis bagaimana penggambaran film atas tokoh utama dari ketika film tersebut yakni Soegijapranata, BJ Habibie dan Hasyim Asy'ari. Meskipun menyajikan dan menganalisa aspek historis tetapi artikel ini tidak bisa dikateforikan sebagai tulisan sejarah karena metode yang digunakan untuk menyajikan data dan menganalisisnya tidaklah menggunakan metode penelitian sejarah.

Jika kata 'nasionalisme' disebutkan maka yang terbesit kemudian adalah kata cinta, komitmen, emosional, atau rasa memiliki terhadap tanah air, bangsa dan negara. Oleh karena itu, nasionalisme terkadang buta, itulah mengapa Benedict Anderson menyatakan bahwa "nation (bangsa) adalah suatu komunitas politik yang terbatas dan beradaulat yang dibayangkan (imagined communities). Komunitas politik itu dikatakan sebagai imagined communities sebab suatu komunitas tidak mungkin mengenal seluruh warganya, tidak mungkin saling bertemu, atau saling mendengar. Akan tetapi, mereka memiliki gambaran atau bayangan yang sama tentang komunitas mereka. Inilah hal yang aneh menurut Ben dan karena hal inilah sebuah bangsa bisa terbentuk. Namun, tentu dengan syarat jika sejumlah warga dalam suatu komunitas mau menetapkan diri sebagai suatu bangsa yang mereka angankan atau bayangkan" (Anderson, 2012, 15). Oleh karena komitmen dan keinginan untuk mengikatkan diri dalam komunitas bangsa ini, dapat muncul kesetiaan yang tinggi pada nation state (negara kebangsaan). Bahkan, banyak warga suatu negara kebangsaan rela mengorbankan jiwa-raga untuk membela bangsa dan negara mereka. Menguatkan pendapat Ben, Ernest Renan mengatakan bahwa unsur utama dalam pembentukan suatu bangsa adalah le desir de'etre ensemble (keinginan untuk bersatu) (Abdullah, 2001, 49). Persatuan inilah yang menurut Dewi Yuliati kemudian membangun solidaritas dan identitas yang satu (Yuliati, 2009).

Menurut Ita Muriara Dewi, nasionalisme tidak bisa dilepaskan dari unsur konsep nation, nasional dan isme. Nasionalisme bukan merupakan ideologi karena ideologi lebih bersifat mendalam. Ideologi adalah pemikiran yang mendasar dan menyeluruh tentang manusia, alam dan kehidupan yang memunculkan aturan atau sistem operasional dalam menjalankan berbagai aspek kehidupan. Nasionalisme secara konseptual memiliki makna yang beragam. Ada yang mengartikan nasionalisme sebagai (1) kulturnation dan staatnation; (2) loyalitas (etnis dan nasional) dan keinginan menegakkan negara; (3) identitas budaya dan bahasa, dan sebagainya (Dewi, 2008: 1).

Satu hal yang perlu diperhatikan bahwa terminologi nasionalisme memiliki perbedaan dengan patriotisme, chauvimisme dan primordialisme Patriotisme adalah sikap seseorang yang bersedia mengorbankan segala-galanya untuk kejayaan dan kemakmuran tanah airnya atau semangat cinta tanah air. Chauvinisme adalah paham (ajaran) cinta tanah air secara berlebih-lebihan sehingga melahirkan sentimen kepada warga negara lain yang besar dan cenderung merendahkan yang lain. Meskipun demikian, antara nasionalisme, patriotisme dan chauvinisme sama-sama berkaitan dengan paham cinta tanah air atau bangsa/negaranya dalam institusi negara bangsa (nation-state).

Kaitan film dan nasionalisme tentu bisa ditarik benang merahnya bahwa 
citra yang dibangun oleh film untuk menggambarkan ketokohan seseoranglah yang diharapkan menjadi modal sosial sebuah kelompok untuk menunjukkan seberapa besar jasa, pengorbanan ataupun pengabdian yang telah diberikan kepada bangsa dan negara. Selain itu, film juga berfungsi untuk menunjukkan faktafakta yang selama ini masih kabur atas seorang tokoh dalam sebuah peristiwa yang justru menjadi titik poin kecintaan terhadap tanah air yang memang sengaja dikonstruk oleh film tersebut. Dan film berlatar sejarahlah salah satu yang bisa menghadirkan citra nasionalisme ini.

Sejak 1998, telah hadir banyak film berlatar belakang sejarah dalam layar lebar Indonesia, namun untuk menyajikan artikel ini, perlu mempersempit kategorisasi film berlatar belakang tersebut menjadi film yang berlatarkan peristiwa faktual, tidak fiktif dan mengangkat tokoh utama yang tidak fiktif pula. Jadi, berdasarkan pembatasan itu, yang terkategorikan film berlatar sejarah di Indonesia, antara lain Gie (2004), Sang Pencerah (2010), Soegija (2012), Habibie-Ainun (2012) dan Hadrotussyaikh Sang Kiai (2013). Sebelum 1998, pada era 1980an juga sudah pernah ada dua film berlatar sejarah yang dirilis yakni Kartini (1981) dan Tjoet Nyak Dien (1988).

Gie mengisahkan tentang aktivis Tionghoa, Soe Hok Gie yang meninggal pada 1966. Film ini berlatar tahun 1960an ketika pengaruh komunisme menguat di Indonesia dan mempengaruhi ideologi gerakan mahasiswa ketika itu. Sedangkan Sang Pencerah berlatar tahun 1868 ketika Ahmad Dahlan lahir hingga ia mendirikan Muhammadiyah pada 1912. Film ini memvisualkan modernitas $\mathrm{KH}$. Ahmad Dahlan dalam memahami Islam dan menghadapi tradisi kebudayaan yang membelenggu.

Soegija yang berlatar pada 19401949 menceritakan kisah Soegijapranata, seorang Jesuit Katolik pribumi pertama yang menunjukkan dukungan kepada Republik yang juga memindahkan keuskupan Semarang ke Yogyakarta ketika ibukota berpindah dari Jakarta ke Yogyakarta setelah perjanjian Renville. Dan terakhir, Hadrotusyaikh Sang Kiai menceritakan riwayat KH. Hasyim Asy'ari, pendiri Nahdhotul Ulama' pada kurun 1938 hingga meninggalnya pada 1947. Kedudukannya sebagai pemimpin pesantren Tebuireng dan Ketua Masyumi dihadapkan dengan kepentingan Jepang ketika menduduki Indonesia. Sedangkan Habibie dan Ainun mengisahkan perjalanan hidup BJ Habibie, presiden ketiga RI mulai ketika duduk di bangku SMA yang di sana dia bertemu dengan Ainun yang kelak dinikahinya pada 1962 sampai meninggalnya istrinya pada Mei 2010. Film ini tidak sekedar menghadirkan adegan cinta antara keduanya, tetapi juga menghadirkan kisah Habibie mulai dari menjadi Menristek hingga presiden RI ketiga. Film -film tersebut seperti halnya otobiografi yang dikemas dengan media lain karena memuat beberapa sekuel perjalanan hidup masing-masing dan pernyataan sikap dan pilihan langkah dalam perjalanan hidup mereka.ku atau website yang sesuai.

\section{HASIL DAN PEMBAHASAN Film Soegija}

Mgr Albertus Soegijapranata SJ adalah Uskup Katholik pribumi pertama yang diangkat oleh Paus Pius XII pada 1940. Sebagai seorang pribumi, kedudukan sebagai seorang Jesuit sangat stategis karena posisi yang diemban Soegija adalah pemimpin ummat Katholik di Indonesia yang berkedudukan di Semarang. Sebelumnya dia diangkat, di Hindia Belanda sendiri seluruh Jesuit berasal dari Eropa Mgr Peter Johannes Willekens SJ sebagai Vikaris Apostolik yang berkedudukan di Batavia; Mgr 
Mattia Leonardo Trudone Brans OFMCap, Vikaris Apostolik di Padang; Mgr Tarcisius Henricus Josephus van Valenberg OFMCap, Vikaris Apostolik di Pontianak; dan Mgr Heinrich Leven SVD, Vikaris Apostolik Isole della Piccola Sonda di Ende, Flores. Artinya, secara sosiologis bisa dijelaskan bahwa Soegija punya kedudukan sosial yang tinggi dan sejajar dengan uskup-uskup Eropa yang lain. Diangkatnya uskup pribumi pada 1940 bisa dilihat dari sudut politik bahwa posisi Belanda yang semakin melemah akibat Perang Dunia II dan desakan Jerman memaksa mereka untuk mengatur strategi untuk mempertahankan struktur keuskupan. Memilih seorang pribumi untuk menjadi uskup menjadi pilihan terbaik ketika kelak mereka harus meninggalkan Hindia -Belanda.

Film yang rilis pada 7 Juni 2012 dan berdurasi 118 menit ini menceritakan tentang kehidupan Soegijapranata pada kurun 1940-1949 yang melintasi tiga zaman Hindia-Belanda, Jepang dan pascaproklamasi kemerdekaan. Ketika Jepang datang ke wilayah Hindia-Belanda pada 1942, Jepang berusaha menguasai seluruh aset yang dimiliki Belanda, termasuk Gereja Katedral Randusari, Semarang. Soegija yang menjadi uskup di sana melawan dengan mempertahankan otoritas dan hak milik gereja. Satu kalimat yang disampaikan Soegija kepada pimimpin Jepang ketika itu adalah bahwa "Gereja Katolik bukan bagian dari Pemerintah Hindia Belanda, melainkan berada di bawah Pemerintah Vatikan, yang juga punya hubungan diplomatik dengan Pemerintah Jepang." Artinya, Jepang tidak bisa menduduki gereja tersebut. Film ini juga menggambarkan bagaimana situasi pendudukan Jepang dan perang mempertahankan kemerdekaan yang banyak memakan korban perempuan dan anak-anak. Unsur kemanusiaan yang dilanggar oleh perang coba disuarakan oleh film ini.
Film Soegija mencoba menghadirkan sikap dukungan kepada pemerintah Republik Indonesia pascaproklamasi kemerdekaan. Setelah ditandatanganinya perjanjian Renville yang membatasi wilayah Republik Indonesia hanya mempunyai wilayah di Yogyakara, maka Romo Soegija memindahkan keuskupan yang berkedudukan di Semarang untuk pindah ke Yogyakarta dan menempati Gereja Bintaran. Satu quote Soegija dalam film yang menggambarkan loyalitasnya atas Republik Indonesia adalah "Seratus persen Katolik itu ya seratus persen Republik". Petikan kalimat Soegija itu bisa dilihat bahwa film ini ingin menghadirkan wajah lain nasionalisme yang juga muncul dari kalangan Katolik. Loyalitas orang-orang Katolik untuk mendukung Republik juga ditampilkan dalam adegan perang, perlindungan yang diberikan otoritas gereja kepada para pengungsi dan para pejuang yang tentunya dibalut dengan unsur dan identitas Katolik.

Siapa di balik film ini? Film ini diolah di Studio Audio Visual Puskat Yogyakarta dan diproduseri oleh oleh Djaduk Ferianto, Murti Hadi Wijayanto SK, Tri Giovani yang menghabiskan 12 miliar rupiah. Sutradara film ini adalah Garin Nugroho. Bisa dijelaskan bahwa keinginan untuk menampilkan nasionalisme dari kaum Katoliklah yang kemudian mendorong Puskat Yogyakarta menghadirkan film ini dalam rangka mengimbangi narasi nasionalisme Indonesia yang cenderung beridentitas Islam.

\section{Film Habibie dan Ainun}

Film yang disutradarai oleh Faozan Rizal ini hadir tidak lama setelah BJ. Habibie melalui The Habibie Center-nya menerbitkan buku memoar yang berjudul sama Habibie dan Ainun pada November 2010. Sekilas yang tampak dari film yang 
rilis 20 Desember 2012 ini adalah film percintaan yang menceritakan kisah cinta Habibie dan istrinya, Hasri Ainun, tetapi jika dicermati lebih dalam ternyata, film ini juga memuat beberapa quote politik Habibie ketika ia mendapatkan kepercayaan sebagai Menteri Riset dan Teknologi (Menristek) RI (1978-1997) ketika Presiden Soeharto menjabat hingga ia ditunjuk sebagai Wakil Presiden (1997-1998) dan Presiden RI (19981999). Bahkan, cerita berunsur politik beberapa saat menjelang Habibie dipanggil kembali ke Indonesia setelah menyelesaikan studinya pada 1965 dan menjadi wakil presiden perusahaan kosntruksi pesawat MBB (1973-1978) di Jerman oleh Soeharto juga dihadirkan dalam film ini.

Film karya MD Pictures dan diproduseri oleh Dhamoo Punjabi dan Manooj Punjabi ini bermula ketika Habibie masih duduk di bangku SMA dan kenal dengan salah seorang teman sekelasnya yang bernama Hasri Ainun Besari. Selepas SMA, Habibie melanjutkan ke Jurusan Teknik Mesin Institut Teknologi Bandung sedangkan Ainun ke Jurusan Kedokteran Universitas Indonesia. Selepas studi, Habibie melanjutkan ke Rhenisch Wesfalische Tehnische Hochscule. Jerman pada 1955. Mereka dipertemukan kembali di Indonesia ketika Habibie harus menjalani masa-masa pengobatan ketika mengidap penyakit TBC tulang saat menjalani studi di Jerman. Pertemuan itu kemudian membawa mereka berdua menuju jenjang pernikahan. Habibie pun membawa Ainun ke Jerman untuk menemaninya menjalani studi S3 di Aachen. Beberapa saat kemudian, Ainun juga mengambil spesialis anak di Jerman dan lulus sebagai dokter spesialis anak.

Perjalanan Habibie selanjutnya berlanjut di Jerman ketika bekerja di Messerschmitt-Bölkow-Blohm atau MBB Hamburg (1965-1969 sebagai Kepala Penelitian dan Pengembangan pada
Analisis Struktrur Pesawat Terbang, dan kemudian menjabat Kepala Divisi Metode dan Teknologi pada industri pesawat terbang komersial dan militer di MBB (1969-1973). 4 tahun kemudian, atas kinerja yang baik, ia dipercaya sebagai Vice President sekaligus Direktur Teknologi di MBB periode 1973-1978 serta menjadi Penasihast Senior bidang teknologi untuk Dewan Direktur MBB (1978). Ketika itu, dialah satu-satunya orang Asia yang berhasil menduduki jabatan nomor dua di perusahaan pesawat terbang Jerman ini. Selama bekerja di MBB Jerman, Habibie menyumbang berbagai hasil penelitian dan sejumlah teori untuk ilmu pengetahuan dan teknologi di bidang Thermodinamika, Konstruksi dan Aerodinamika. Beberapa rumusan teorinya dikenal dalam dunia pesawat terbang seperti "Habibie Factor", "Habibie Theorem" dan "Habibie Method".

Ketika Habibie berada di puncak karirnya dalam industri pesawat terbang, ia diminta kembali ke Indonesia oleh Presiden Soeharto. Dia diyakinkan bahwa Indonesia sudah menunggu kiprah Habibie. Puncak karir itupun ditinggalkan. Inilah salah satu bentuk nasionalisme yang dihadirkan oleh film ini. Pilihan bekerja di tempat yang nyaman untuk pengembangan karirnya dan gaji yang besar harus ditinggalkan untuk memenuhi panggilan negara. Dijemput langsung oleh Ibnu Soetowo yang ketika itu menjadi salah satu orang kepercayaan Soeharto, setibanya di Indonesia dia langsung diantar menghadap Soeharto. Dalam kesempatan itu, Habibie memaparkan rencananya dalam membangun industri pesawat terbang sebagai industri strategis nasional yang mempunyai beribu-ribu pulau. Film ini juga menampilkan sosok orang yang mencoba merebut grand desain perancangan industri pesawat 
yang masih dalam proses diajukan Habibie kepada Soeharto yang menyiratkan bahwa Habibie ingin menyuarakan bahwa banyak orang-orang yang berkepentingan atas rencana Habibie itu.

$$
\text { Perjalanan Habibie sebagai }
$$
Menristek RI (1978-1997) tidaklah mulus. Wewenang yang diberikan Soeharto yang terlampau besar dengan menjadi Kepala Badan Pengkajian dan Penerapan Teknologi (PPPT) dan Dewan Riset Nasional membuat lawan-lawan politik yang kecewa karena gagal mengambil keuntungan atas langkahnya dalam pengembangan industri pesawat terbang nasional menekan dengan menghembuskan isu bahwa usaha Habibie hanyalah memboroskan APBN. Pada adegan ini, Habibie sebenarnya ingin mengatakan bahwa industri pesawat terbang adalah investasi jangka panjang yang tidak murah harganya, maka wajar jika investasi negara untuk hal ini juga besar. Puncaknya, pada 1995 ketika pesawat CN-250 'Gathotkaca' akan diterbangkan perdana sempat diterpa isu bahwa Presiden Soeharto berhalangan untuk hadir.

Statemen politis Habibie dalam film ini juga muncul ketika harus mengizinkan lepasnya Timor Timur menjadi negara berdaulat pada 1999. Tekanan dunia internasional dikarenakan tidak bisa terkontrolnya TNI di sana dengan baik ketika gejolak mulai terjadi, terus menguat. Referendum menurut Habibie dalam film tersebut menjadi pilihan terbaik. Konsekwensinya, lawan-lawan politik Habibie muncul di banyak media cetak dan elektronik dan mencibir Habibie bahwa dia hanyalah seorang insinyur maka tidak pantas menjadi presiden. Melalui film ini, Habibie ingin menjawab bahwa jabatan presdien tidaklah menjadi ambisi pribadi dia. Maka keputusan-keputusan berat yang harus dia ambil setelah turunnya Presiden Soeharto sama sekali tidak bermuatan politik yang menguntungkan salah satu golongan. Menurutnya, keputusan paling logis dan rasional lah yang harus diambil. Tanpa dukungan partai politik karena memang dia tidak memilih partai sebagai kendaraan politiknya, Habibie akhirnya ditutunkan dalam Sidang Istimewa MPR RI 1999 yang menghasilkan keputusan untuk melaksanakan pemilihan umum untuk memilih Presiden RI yang baru.

\section{Film Hadrotussyaikh Sang Kiai}

Film yang rilis 30 Mei 2013 ini menghadirkan kisah KH. Hasyim Asyari, pemimpin pondok Tebuireng, Jombang sekaligus pendiri Nahdhatul Ulama'. Film ini bermula pada kurun jelang datangnya Jepang ke wilayah yang disebut Hindia Belanda setelah memenangkan Perang Asia Timur Raya. Kiai Hasyim tinggal di wilayah pedalaman Jombang yang mayoritasnya adalah petani. Salah satu potongan kehidupan pesantren Tebuireng pada 1930an dihadirkan oleh film ini dengan proses penerimaan santri baru yang menggunakan hasil bumi sebagai pembayarannya. Selebihnya, pesantren berusaha mandiri dengan mencukupi kehidupan sehari-hari santri dan kiainya dengan menanam padi dan dikelola oleh para santri sendiri. Kehidupan pesantren yang damai kemudian berubah ketika Jepang datang ke sana dan hendak menangkap Kiai Hasyim dengan tuduhan memprovokasi masyarakat untuk berdemo di pabrik gula Tjoekir, Jombang. Kiai Hasyim pun bersedia ikut dengan pasukan Jepang dan ditawan di penjara Jombang.

Ikatan pratron-klien antara klai dan santri digambarkan dengan jelas dalam film ini. Ketika Kiai Hasyim ditangkap, gelombang demontrasi dari para santri terus mengalir. Beberapa kali penjara Jombang didatangi oleh para santri Tebuireng. Bahkan ketika Kiai Hasyim dipindahkan ke penjara Mojokerto pun, santri-santri tetap berdatangan untuk 
meminta kiainya dibebaskan. Mereka berdemo dengan cara damai yakni dengan membaca shalawat. Cara ini diambil setelah cara kekerasan dilakukan di penjara Jombang tidak membuahkan hasil, bahkan justru memakan banyak korban jiwa dari para santri. Lobi awal di penjara ketika Jepang diyakinkan bahwa Tebuireng mempunyai pengaruh yang besar di Jawa Timur dan Madura tidak digubris Jepang. Pada adegan itu, film ini mencoba menunjukkan kebesaran pesantren Tebuireng dan sosok Hasyim Asyari di mata masyarakat Jawa Timur dan Madura.

Dalam penjara, Hasyim Asy'ari
dipaksa untuk menandatangani
pernyataan bahwa dia adalah yang
memprovokasi masyarakat untuk
berdemo di Tjoekir dan bersedia
melaksanakan sakerei (penghormatan
kepada Dewa Matahari) yang dilakukan
oleh pasukan Jepang setiap pagi. Film ini
memvisualkan bahwa permintaan itu
ditolak oleh Kiai Hasyim. Dia punya
prinsip teguh bahwa aqidah Islam
melarang sakerei karena berarti
mengakui Tuhan lain selain Allah. Kiai
Hasyim pun terus disiksa bahkan pada
suatu ketika, penyiksaan itu didengarkan
dengan pengeras suara kepada pada
demonstran yang Has menuntut
dibebaskannya Kiai Hasyim. Situasi
berubah ketika lobi yang dilakukan
Wahid Hasyim, putranya kepada
pemerintah militer Jepang di Jakarta atas
bantuan seorang Jepang, berhasil.
Kebijakan Pemerintah Militer Jepang
kemudian memilih menggunakan para
kiai untuk bisa meluaskan
propagandanya di Indonesia yang
mayoritas Islam.

Setelah dibebaskan dari penjara, legitimasi besar Hasyim Asy'ari dan Tebuireng dimanfaatkan oleh Jepang sebagai ketua Masyumi, gabungan organisais-organisasi Islam. Salah satu peristiwa yang divisualkan dalam film ini adalah ketika Masyumi ditekan oleh
Jepang untuk memaksa masyarakat untuk meningkatkan hasil bumi untuk kebutuhan Jepang. Masyumi pun menulis pada buletin yang disebarkannya di masyarakat dan kemudian menuai kontroversi. Film ini menampilkan jawaban Hasyim Asy;ari terkait kontroversi dalam kasus instruksi meningkatkan hasil bumi bahwa Masyumi adalah alat Jepang untuk memeras rakyat. Statemen Hasyim Asy'ari yang dimunculkan dalam film tersebut adalah bahwa yang dia maksudkan adalah penyerahan hasil bumi itu kepada pemimpin yang tidak dhalim kepada rakyat. Artinya, adegan itu menjadi jawaban bahwa Masyumi sebenarnya tidak serta merta menginstruksikan pelipatgandaan hasil tapi secara inplisit juga menuntut Jepang agar berbuat adil dan tidak dholim kepada masyarakat ketika memang kemudian beras sudah diserahkan kepada mereka.

Adegan lain yang dimunculkan dalam film ini adalah ketika Jepang kalah dalam perang Pasifik dan harus meninggalkan Indonesia. Sekutu dan diboncengi NICA menyebarkan brosur bahwa rakyat harus meninggalkan Surabaya dalam 2x24 jam. Dalam rangka merespon hal itu, Kiai Hasyim diminta fatwa oleh Bung Tomo dan kemudian lahirlah Resolusi Jihad 22 Oktober 1945 yang berisikan kewajiban untuk memerangi orang kafir, derajat yang akan diraih oleh pejuang pembela tanah air adalah syuhada' dan orang yang bekerjasama dengam Belanda adalah wajib dibunuh. Resolusi Jihad yang dikeluarkan PBNU itu mengobarkan semangat para santri dan elemen masayrakat lain di Jawa Timur khususnya yang memang basis NU dengan membentuk pasukan Hizbullah. Pesantren Tebuireng mengirim cukup banyak santri untuk menyambut kedatangan pasukan NICA di Surabaya. 
Film ini secara implisit menyatakan bahwa pasukan Hizbullah lahir di Tebuireng dan Kiai Hasyim mempunyai peran besar atas kelahiran pasukan Hizbullah di berbagai wilayah lain di luar Jombang.

Nasionalisme Kiai Hasyim yang telah coba dihadirkan oleh film ini memang sarat sudut pandang Islam dan NU. Film yang diproduseri oleh Gope T. Samtani dan disudradarai oleh Rako Prijanto ini digarap di studio Rapi Films. Satu hal lain yang menarik dari film ini adalah upaya untuk merekonstuksi sejarah yang menurut saya sangat kontroversial. Ada sosok fiktif yang dihadirkan dalam film ini yang bernama Harun, seorang santri Tebuireng. Dial ah yang divisualkan oleh film ini sebagai pembunuh Brogadir Jendral Aubertin Mallaby, komandan pasukan Inggris saat datang ke Surabaya pada 30 Oktober 1945 sebelum akhirnya mobil Mallaby yang sering dihadirkan dalam buku-buku sejarah meledak. Peristiwa inilah yang menjadi salah satu penyebab pecahnya peristiwa 10 November 1945 di Surabaya.

\section{KESIMPULAN}

Film sejarah layaknya sebuah tulisan sejarah, akan hadir dengan subjektivitas yang dibangun. Subjektivitas inilah yang kemudian mendorong untuk memunculkan ke'akuan' dalam perjalanan hidup seorang tokoh. Subjektivitas inilah yang juga menghadirkan citra nasionalisme yang coba disajikan secara natural oleh filmfilm berlatar belakang sejarah. Citra nasionalisme dalam film-film tersebut seperti halnya kontestasi untuk menunjukkan banyak hal yang menyangkut tentang kecintaan, jasa besar, dan kontribusi terhadap bangsa yang belum diketahui oleh khalayak dan belum tercatat dalam buku-buku sejarah. Terkecuali BJ Habibie, gelar pahlawan nasional yang sudah diraih oleh
Soegijapranata dan Hasyim Asy'ari ternyata belum cukup bagi orang-orang di sekililingnya untuk menunjukkan betapa besar bentuk 'kepahlawanan' yang sudah dilakukan dan nasionalisme yang ditunjukkan untuk bangsa dan negara.

Nasionalisme yang dihasilkan oleh film-film berlatar sejarah seperti ini adalah nasionalisme primordial yang masih menonjolkan keagamaan ataupun golongan tertentu. Apa yang ditunjukkan Soegija tentu adalah nasionalisme Katolik karena pesan yang ingin disampaikan pembuat film adalah kontribusi kaum Katolik dalam perjuangan bangsa. Begitu juga dengan Sang Kiai, nasionalisme yang ditunjukkan dari sosok KH. Hasyim Asy'ari dan para santri pesantren Tebuireng adalah nasionalisme golongan Islam. Sedangkan dalam Habibie dan Ainun lebih menonjolkan nasionalisme kebangsaan yang memang dihadirkan untuk 'membela diri' dari pandanganpandangan sinis mengenai Habibie sepanjang kiprahnya dalam birokrasi Republik Indonesia dari tahun 1979 hingga 1999.

Film ini memang disajikan dalam layar lebar dan sepanjang tayang di bioskop telah mencat kuantitas penonton yang berbeda. Habibie dan Ainun yang mencapai angka tertinggi, hingga 4,1 juta penonton. Sedangkan Soegija dan Sang Kiai berkisar antara 1-2 juta. Habibie dan Ainun meraih lebih banyak dikarenakan 'kenetralan' film yang disajikan. Sedangkan Soegija dan Sang Kiai yang 'segmented' untuk golongan Katolik dan Islam (meskipun sebenarnya juga ditujukan untuk semua) berimbas pada jumlah penonton yang terbatas. Namun, yang akan dilihat kaitannya dengan pembahasan citra kepahlawanan bukanlah kuantitas namun seberapa jauh kemudian film-film menjadi propaganda yang mendekonstruksi pemahaman masyarakat selama ini. Memang belum bisa dilihat lebih jauh mengenai hal ini. 
Satu hal yang bisa dilihat adalah legitimasi yang berhasil didapatkan dari masing-masing yang menyuarakan dan membuat film ini.

\section{DAFTAR PUSTAKA}

Anderson, B. (2012). Imagined Community. Yogyakarta: Pustaka Pelajar.

Asvi Warman Adam. (2007). Pelurusan Sejarah Indonesia. Yogyakarta: Ombak.

Dewi Yuliati. "Menyibak Fajar Nasionalisme Indonesia". Makalah Sarasehan Sejarah Regional Daerah Dinas Kebudayaan dan Pariwisata Provinsi Jawa Tengah, di Hotel Pondok Tingal Magelang, 23 Mei 2009. Diunduh via Google.

Irawanto, Budi. (2018) Film, Ideologi, dan Militer: Hegemoni Militer dalam Sinema Indonesia. Yogyakarta: Warning Books \& Jalan Baru.

Ita Mutiara Dewi. "Nasionalisme dan Kebangkitan dalam Teropong" dalam Mozaik Vol.3 No. 3, Juli 2008. Diunduh via Google.

Kementrian Sosial RI. "Prosedur Pengusulan Gelar Pahlawan Nasional" dalam http://www. kemsos.go.id/modules.php?

name $=$ Pahlawan, diakses pada 24 Juni 2013.

Pusat Bahasa Depdiknas RI. (2008). Kamus Besar Bahasa Indonesia. Jakarta: Pusat Bahasa Depdiknas RI.

Abdullah, T. (2001). Nasionalisme dan Sejarah. Jakarta: Satya Historika.

Van Klinken, G. (2008). “Aku yang berjuang: Sebuah Sejarah
Penulisan tentang Diri Sendiri pada Masa Orde Baru" dalam Perspektif Baru Penulisan Sejarah Indonesia. Jakarta: Obor dan KITLV Jakarta. 